\title{
O ACORDO DE LENIÊNCIA, O CASO “ANEL DE INTEGRAÇÃO” E O REEMBOLSO À SOCIEDADE SOB A ÓTICA DA ANÁLISE ECONÔMICA DO DIREITO (AED)
}

Emerson Ademir Borges de Oliveirai

Celso Ferreira da Cruz Victorianoii

\section{RESUMO}

O presente estudo apresenta uma proposta de análise empírica acerca da celebração de acordos de leniência junto às concessionárias responsáveis pelo Anel de Integração paranaense, no âmbito da Operação Lava Jato, direcionando-se, ao mesmo momento, para a compreensão teórica do instituto inserido na Lei 12.846/2013 (Lei Anticorrupção Empresarial). Noutras palavras, sob a premissa de análise do caso em questão, pretende-se não apenas compreendê-lo sob o aspecto empírico, como também analisar o instituto em debate do ponto de vista teórico. As conclusões decorrem da avaliação do caso sob a égide legal. Ademais, sob a perspectiva da análise econômica do Direito, enquanto um referencial teórico, a análise do caso apresentado remonta aos reflexos à sociedade que decorrem da celebração do acordo de leniência em um duplo sentido: o combate à corrupção e improbidade administrativa e a devolução à sociedade de parcela obtida ao longo dos atos que foram objeto do acordo. Deve-se ressaltar, nessa linha, que, conforme julgamento da ADPF $\mathrm{n}^{\circ} 568$, os recursos recuperados devem retornar para a sociedade.

PALAVRAS-CHAVE: Anel de Integração; Operação Integração; Lei Anticorrupção. Acordo de Leniência; law and economics; análise econômica do direito.

' Universidade de Marília (UNIMAR), Programa de Pós-Graduação em Direito (PPGD), Marília, SP, Brasil, ORCID; "i Universidade de Marília (UNIMAR), Programa de Pós-Graduação em Direito (PPGD), Marília, SP, Brasil, $\underline{\text { ORCID. }}$ 


\title{
THE LENIENCE AGREEMENT, THE CASE “ANEL DE INTEGRAÇÃO” AND THE REFUND TO SOCIETY UNDER THE VIEW OF ECONOMIC ANALYSIS OF LAW (EAL)
}

Emerson Ademir Borges de Oliveira

Celso Ferreira da Cruz Victoriano

\begin{abstract}
This study presents a proposal for an empirical analysis about the signing of a leniency agreements with the concessionaires of the "Anel de Integração", within the scope of Operation Car Wash, aiming, at the same time, towards the theoretical understanding of the institute inserted in Law 12.846 / 2013 (Corporate AntiCorruption Law). In other words, under the premise of analyzing the case in question, it is intended not only to understand it from an empirical point of view, but also to analyze the institute under debate from a theoretical point of view. The conclusions derive from the evaluation of the case under the legal aegis. Furthermore, from the perspective of the economic analysis of Law, as a theoretical framework, the analysis of the case presented goes back to the reflexes to society that result from the conclusion of the leniency agreement in a double sense: the fight against corruption and administrative improbity and the return to company obtained through the acts that were the object of the agreement. It should be noted, in this line that according to the judgment of ADPF 568, the recovered funds must be returned to society.
\end{abstract}

KEYWORDS: Anel de Integração; Integration Operation; Anticorruption Law; Leniency Agreement; law and economics; economic analysis of law. 


\section{INTRODUÇÃO}

Em um amplo contexto de combate à corrupção, a Lei Anticorrupção e o respectivo acordo de leniência urgem como propostas, simultaneamente, repressivas e preventivas. Primeiramente, há de se lembrar que tais acordos, surgidos no direito concorrencial norte-americano, possuem o propósito de incentivar a colaboração dos particulares com o Estado, propiciando melhores condições de instrução e apuração de responsabilidades por atos contra o erário público.

O presente estudo tem como pressuposto o combate à corrupção no Brasil através da Lei n 12.846/2013, ou seja, a Lei Anticorrupção Brasileira, pretendendo, o esforço, sob a perspectiva da análise econômica do direito, compreender a repercussão da Operação Lava Jato no contexto nacional.

Empiricamente, contudo, este trabalho tem por foco de estudo os ajustes celebrados com empresas concessionárias do Anel de Integração paranaense, em decorrência da Operação Integração, na 55a fase da Operação Lava Jato, em virtude da prática de atos lesivos previstos na Lei Anticorrupção e dos ilícitos administrativos previstos na Lei de Licitações ( $n^{\circ}$ 8.666/1993), na qual, pela LAE, a Controladoria-Geral da União (CGU) detém competência exclusiva, no Poder Executivo Federal, para celebrar acordos de leniência com empresas investigadas pela prática de atos contra a Administração Pública.

O acordo de leniência da Lei Anticorrupção atua como eficiente instrumento no combate à improbidade administrativa. Em paralelo à teoria dos jogos, o modelo inspira-se no chamado "dilema do prisioneiro", o qual inspira um dos ofensores a colaborar antes dos demais para que possa usufruir de benefícios significados (Blum et al., 2008, p. 210). Mais do que isso, o presente trabalho tem como propósito estudar a celebração dos referidos acordos de leniência sob a ótica da análise econômica do direito e dos efeitos da teoria dos jogos. Isto é, quais vantagens tais acordos representam, do ponto de vista econômico e do ponto de vista estratégico, para as empresas celebrantes. 
Frise-se, ademais, que a opção do estudo empírico voltado ao Anel de Integração paranaense justifica-se em duas medidas. Em primeiro lugar, como será visto alhures, fatos análogos e geograficamente próximos motivaram a celebração de mais de um acordo, com empresas distintas; em segundo lugar, como será discutido mais ao término do trabalho, tais acordos partiram da discutível iniciativa do Ministério Público Federal. Deve-se ter em mente, outrossim, enquanto paradigma teórico-prático, que, conforme decisão proferida em Medida Cautelar na Arguição de Descumprimento de Preceito Fundamental $n^{\circ} 568$ (Rel. Min. Alexandre de Moraes), os recursos desviados devem retornar à sociedade.

Especificamente, durante uma das fases da Operação Lava Jato, foram celebrados acordos de leniência com concessionárias responsáveis pelo Anel de Integração do Paraná, durante a Operação Integração, os quais motivaram a presente análise. Entre as condições para cumprimento, uma voltava-se ao retorno direto à sociedade, mediante desconto nas praças de pedágio operadas pela concessionária.

Sob a perspectiva da análise econômica do direito, percebe-se o diálogo estabelecido entre os fins do acordo de leniência, a Administração Pública e a sociedade, sendo aquele constituído um instrumento que, além de servir ao combate à corrupção, promove benefícios diretos e indiretos à sociedade.Noutras palavras, o que se persegue é a análise dos impactos dos acordos de leniência celebrados em face do objetivo de se promover, ao mesmo tempo, benefícios à sociedade e desestímulo a práticas que atentem contra o erário público.

\section{REFERENCIAIS TEÓRICOS DO DESENVOLVIMENTO}

\section{A LEI N 12.846/2013: LEI ANTICORRUPÇÃO EMPRESARIAL NA PERSPECTIVA DA ANÁLISE ECONÔMICO DO DIREITO - AED}

O cenário internacional tem assistido, desde a década de 90, um ascendente movimento anticorrupção, os quais tiveram reflexo na confecção de instrumentos 
internacionais com relevante adesão brasileira, no intuito de aprimorar e reforçar os marcos legais no combate à corrupção (Machado, 2017, p. 78).

Dentre os acordos internacionais, Machado (2017, pp. 78-79) menciona a Convenção Interamericana contra a Corrupção de 1996 (Convenção da OEA Organização dos Estados Americanos); a Convenção da OCDE - Organização para a Cooperação e Desenvolvimento Econômico - sobre o Combate ao Suborno de Oficiais Públicos Estrangeiros em Transações Comerciais Internacionais de 1997; e a Convenção das Nações Unidas (ONU) contra o Crime Organizado Transnacional, conhecida como Convenção de Palermo.

Inobstante, deve-se ressaltar que o marco legal a estimular esse movimento internacional pode ser encontrado na lei norte-americana Foreign Corrupt Practices Act (FCPA), de 1977, a qual tinha por objetivo o combate ao suborno praticado por empresas dos Estados Unidos no cenário global. No plano internacional, contudo, como ressalta Machado (2017, pp. 83-85), a agenda anticorrupção desenvolveu-se a partir da mencionada Convenção da OCDE.

Em consequência, surge no cenário brasileiro a necessidade de adoção de políticas efetivas nesta agenda, em especial diante dos reflexos corruptivos no desenvolvimento social e econômico. É neste contexto que, impulsionada pelas manifestações de julho de 2013, surge a Lei Anticorrupção Empresarial (Lei $n^{\circ}$ 12.846/2013), um projeto inicial do ano 2000 ( $P L n^{\circ}$ 6.826), passando a responsabilizar as pessoas jurídicas por atos contra a Administração Pública para além de outros instrumentos legislativos, como a Lei de Licitações.

Suprindo uma lacuna em termos de penalização da pessoa jurídica que pratique atos que causem prejuízo ao erário, a lei sob exame apresenta pontos inovadores, como a responsabilidade objetiva da empresa, sanções aplicadas no plano administrativo, cadastro nacional de empresas punidas, além de outras questões como a tipificação dos atos ilícitos, sanções judiciais, desconsideração da personalidade jurídica e, no que mais nos interessa, a possibilidade de celebração de acordos de leniência.

Note-se que a Lei Anticorrupção não inaugura, mas amplia consideravelmente a responsabilização da pessoa jurídica por atos de corrupção, 
antes restrita basicamente às sanções previstas no artigo 87 da Lei de Licitações, bem como à responsabilização das pessoas naturais dispostas em vários instrumentos normativos, como a Lei de Improbidade Administrativa, a Lei dos Crimes contra a Ordem Econômica e o próprio Código Penal. Aliás, o próprio Decreto $\mathrm{n}^{\circ} 8.420 / 2015$, que regulamenta a Lei, ressalta que as penalidades da LAE não excluem as da Lei de Licitações.

A LAE também não apresenta ao direito brasileiro o acordo de leniência, instrumento disposto na antiga Lei do CADE (Lei $n^{\circ} 8.884 / 94$ ), por força da alteração propugnada pela Lei $n^{\circ} 10.149 / 2000$, conversão da Medida Provisória $n^{\circ}$ 2.055-4, e importado do direito norte-americano. E, embora empreste o instituto, inclusive quanto aos seus detalhamentos, inova ao empregá-lo em virtude das sanções administrativas praticadas pelas pessoas jurídicas em atos de corrupção contra o Estado.

Como conceitua Canetti (2018, p. 17), os acordos de leniência devem ser compreendidos como "instrumentos bilaterais celebrados entre a Administração Pública e um particular, pelo qual o primeiro oferece mitigações ou isenções das penalidades aplicáveis ao segundo, em troca de sua colaboração num processo sancionador".

De acordo com o autor (Canetti, 2018, p. 31), os acordos de leniência, para além da diminuição na duração do processo ou aumento das condenações, possuem como principal objetivo a "mútua traição" entre os agentes corruptos, enfraquecendo suas relações.

É neste ponto que os acordos necessitam de análise sob o prisma da Law and economics e da teoria dos jogos, uma vez que representam vantagens econômicas e estratégicas às pessoas jurídicas que praticaram as atividades ilícitas e ao próprio Estado.

A par das colaborações premiadas celebradas no âmbito das pessoas físicas, a leniência também se fez presente no contexto da Operação Lava Jato, abrindo as cortinas financeiras de grandes e conceituadas empresas privadas e suas relações com o governo. 
Daí o questionamento emergente acerca dos efeitos econômicos que tais inovações e alterações jurídicas trouxeram ao contexto brasileiro.

\section{O ACORDO DE LENIÊNCIA SOB O PRISMA DA LAW AND ECONOMICS}

Sob a ótica da Análise Econômica do Direito, destinada precipuamente à compreensão do comportamento dos indivíduos diante de uma norma jurídica e o resultado econômico desses comportamentos, podemos observar que o acordo de leniência é um instituto que garante a eficiência do Estado como responsável pelo combate a corrupção.

Consoante ensinam Ferreira e Ferreira (2017, p. XL-XLI), no Law and Economics

[...] estuda-se a ação das regras jurídicas (Constituição, leis, atos normativos, decisões judiciais, entre outros) na tomada de decisões e nos resultados da economia. Quando aquela recorre aos procedimentos de análise da Economia Neoclássica, ela pressupõe que o Direito também enfrenta a escassez de recursos para concretizar seus objetivos (tal como ocorre com a Economia), de maneira que, ao alocar recursos em cada um desses objetivos, isso se daria em detrimento da destinação de recursos para as demais metas.

Conforme ensinamentos de Márcia Ribeiro e Vinícius Klein (2016, pp. 20-21), trata-se de um método de investigação para tentar compreender, explicar e prever as implicações fáticas do ordenamento jurídico, bem como da lógica (racionalidade) do próprio ordenamento jurídico, utilizando uma abordagem econômica para tentar compreender o direito no mundo e o mundo no direito.

Outrossim, como destacado por Coase (2017, p. 5):

O diferencial dos ensaios que compõem este livro não está em rejeitarem a teoria econômica existente, a qual, como disse, personifica a lógica da escolha e tem ampla aplicabilidade, mas em empregarem a teoria 
econômica para examinar o papel que a firma, o mercado e o direito desempenham no funcionamento do sistema econômico.

Em complemento, conforme Pinheiro e Saddi (2005, pp. 83-84):

Assim, o movimento de Direito \& Economia vem a ser uma corrente acadêmica de juristas e economistas que procura analisar o fenômeno jurídico sob uma óptica comum, baseada em princípios econômicos. Essa linha de pensamento, concebida originalmente como uma vertente das escolas econômicas mais liberais, foi logo abarcada pelas faculdades de Direito. Seus enunciados olham o direito como um sistema que aloca incentivos e responsabilidades dentro do sistema econômico, como o da eficiência.

Ademais, como já dissemos, a AED possui três premissas de aplicação. Em primeiro lugar, os indivíduos, dada sua racionalidade, "orientam suas escolhas à maximização dos seus interesses" e "para tanto, reagem a incentivos, fazendo escolhas conforme a utilidade aos seus interesses". Em segundo lugar, volta-se ao equilíbrio, uma vez que as ações individuais devem influenciar o mercado de maneira equilibrada. Em terceiro, considerando que os recursos são escassos, mas as necessidades são crescentes, prima-se pela eficiência (Borges de Oliveira \& Payão, 2018, p. 209).

Note-se que o princípio da eficiência se apresenta como um dos fundamentos da Análise Econômica do Direito, uma vez que busca interpretar os acontecimentos e atos da administração pública em razão de seu alcance a favor da sociedade.

É este contexto que remonta à teoria do sociólogo Vilfredo Pareto, conhecida como "Ótimo de Pareto", a qual deve ser compreendida como o exato momento de equilíbrio em que todas as ações a serem tomadas não incrementam a condição dos agentes sem prejudicar outros, sendo que, nesse exato momento, está caracterizado o critério de eficiência de Pareto (Ribeiro \& Klein, 2016, p. 38). 
Nessa linha de raciocínio, Vilfredo Pareto defendeu que existe um ponto em há equilíbrio dos interesses dos agentes, diante do qual o aumento de qualquer condição pode levar uma das partes a perdas. O "Pareto Eficiente" constitui o momento em que não há como aumentar o benefício de qualquer uma das partes sem prejudicar o outro (Ribeiro \& Klein, 2016, p. 39).

Além do "Ótimo de Pareto", a Law and Economics também se vale do modelo eficiente de "Kaldor-Hicks". Nesse caso, "dada situação é considerada eficiente quando o prejuízo causado a determinada parte é menor do que o proveito da coletividade, possibilitando que as perdas possam ser compensadas pelos ganhos, gerando a maximização da riqueza social" (Borges de Oliveira \& Payão, 2018, pp. 209-210).

Contudo, em termos práticos, a partir do Teorema de Coase, a conduta de um agente que cause prejuízo a outro não deve ser punida sem que se pondere se o prejuízo da punição será mais ou menos prejudicial economicamente do que a prática inicial, conforme exposto no escrito "O problema do custo social"(COASE, 2017, pp. 104-119).

Sob este prisma, pontua Fábio Ulhoa Coelho (1995, p.162):

A implicação jurídica do teorema é a de que, para contribuir à realização da eficiência, a ordem positiva não precisa necessariamente atribuir direitos e deveres para esta ou aquela pessoa, nas situações em que os custos de transação são desprezíveis. Pois nesses casos, segundo afirma o teorema, é indiferente a pessoa a quem se imputa a responsabilidade, para fins de garantir a eficiência da solução judicial.

A partir disso, assevera Coase (2017, p. 119) que o alto custo das transações de mercado impossibilita uma definição clara de direitos e previsão das ações judiciais. Daí sua conclusão de que os tribunais influenciam a atividade econômica diretamente e de que existe a necessidade de inserção dos custos de transação positivos na análise econômica (Coase, 2017, p. 16). 
Inserto ao objeto de análise do estudo, deve-se mencionar a base teórica inscrita na Teoria dos Jogos, desenvolvida por Von Neumann, em 1928, e posteriormente retomada, em 1944, em obra em coautoria do Oskar Morgenstern, para o qual o ganho de um jogador representa a perda equivalente sofrida pelo outro (Ribeiro \& Klein, 2016, pp. 118-124).

É nesta perspectiva que se ilustre o "dilema do prisioneiro", na qual se busca estudar os processos de tomada de decisões por agentes racionais em situações estratégicas, isto é, circunstâncias em que o indivíduo deve agir tendo em consideração a possível escolha de outro agente, e vice-versa (Canetti, 2018, pp. 6566).

A partir da Teoria dos Jogos, John Nash, John C. Harsanyi e Richard Selten foram laureados Prêmio de Ciências Econômicas em Memória de Alfred Nobel, em 1994, com a apresentação do chamado "Equilíbrio de Nash", segundo o qual o equilíbrio existe quando todos os jogadores ficam satisfeitos com as suas respectivas estratégias e auferem ganhos.

Munidos desses referenciais teóricos, passa-se à análise, com mais riqueza de detalhes, do acordo de leniência na Lei Anticorrupção.

De acordo com o artigo $16, \S 7^{\circ}$, da LAE, o acordo de leniência exige, para ser firmado, a presença de alguns requisitos, a saber:

I - A pessoa Jurídica seja a primeira a se manifestar sobre o seu interesse em cooperar na apuração do ato ilícito;

II - A Pessoa Jurídica cesse completamente o envolvimento e a prática da infração investigada a partir da data da propositura do acordo;

III - A Pessoa Jurídica admita sua participação no ilícito e coopere plena e permanentemente com as investigações e processo administrativo; comparecendo sob suas expensas, sempre que; solicitada, a todos atos processuais, até seu encerramento.

Especialmente quanto ao acordo de leniência, como será demonstrado, sobreleva uma vertente explícita da teoria dos jogos acima mencionada. Note-se 
que o primeiro requisito legal para sua celebração, consoante a Lei Anticorrupção, é justamente ser a pessoa jurídica a primeira a se manifestar sobre o interesse na cooperação da apuração do ilícito. Percebe-se que, quando o ato ilícito envolve mais de uma pessoa jurídica, paira no ar a dúvida acerca da adesão primária, delatando o outro partícipe e obtendo os benefícios da lei, ou arriscar-se a permanecer inerte e acabar sendo a empresa delatada por aquela que pleiteou o benefício primeiro.

Insta consignar que a competência para que venha a ser firmado é da autoridade máxima de cada órgão ou utilidade pública. No âmbito federal, por força do $\$ 10^{\circ}$ do artigo 16, essa competência será da Controladoria-Geral da União, com participação da Advocacia-Geral da União (artigo $3^{\circ}, \S 2^{\circ}$, da Portaria CGU/AGU 2278/2016).

Impende destacar, ainda que introdutoriamente, que, conforme $\S 2^{\circ}$ do artigo 16 da LAE, a celebração do acordo de leniência isentará a pessoa jurídica da publicação extraordinária da decisão condenatória (na esfera administrativa) e da proibição de receber incentivos, subsídios, subvenções, doações ou empréstimos de órgãos ou entidades públicas e de instituições financeiras públicas ou controladas pelo poder público, pelo prazo mínimo de 1 (um) e máximo de 5 (cinco) anos (na esfera judicial). Além disso, reduzirá em até $2 / 3$ (dois terços) a multa administrativa aplicável. Não obstante, o acordo não exime a obrigação de reparar integralmente o dano causado (art. 16, $\S 3^{\circ}$ ).

Note-se, assim, que os efeitos da leniência possibilitam ganhos consideráveis ao acordante e resultado útil ao Estado, tanto em termos de apuração da infração quanto em retorno aos cofres públicos de recursos desviados para que se destinem às finalidades estatais dispostas na Constituição.

Como destaca Carvalhosa (2015, p. 371):

[...] no contexto da presente Lei (o acordo de leniência) representa um pacto de colaboração firmado entre a autoridade processante e a pessoa jurídica indicada ou já processada, através do qual se estabelece a promessa de serem abrandadas as Penalidades aqui instituídas (art. $6^{\circ}$ ) uma vez 
alcançada a maior abrangência do concurso delitivo em termos de pessoas jurídicas e/ou de agentes Públicos envolvidos [...].

Aliás, acerca do tema já dissemos:

O acordo de leniência previsto pela Lei n. 12.846/13 tem exatamente esse sentido - o de suavizar as sanções aplicáveis ao que praticar ato lesivo à Administração Pública - em troca de colaboração efetiva da pessoa jurídica, desde que dessa colaboração resulte a identificação dos demais envolvidos na prática do ato ilícito e garanta maior celeridade na obtenção de provas que comprovem a materialidade do ilícito sob investigação. Todavia, somente pode ser signatária do acordo a pessoa jurídica e não uma pessoa física. O acordo de leniência poderá ser celebrado entre a Administração Pública e a pessoa jurídica que praticou o ilícito quando esta atuar de forma satisfatória e eficiente não somente na investigação, mas também no processo administrativo, gerando a identificação dos terceiros envolvidos na lesão e possibilitando o alcance de provas -como as documentais - para subsidiar toda a investigação (Borges de Oliveira \& Ceren, 2019, p. 7).

Por evidente, as vantagens para as empresas não se operam sobre todas consequências jurídicas possíveis quanto aos ilícitos, e nem isenta as pessoas físicas de punições em outras esferas, como as decorrentes de eventuais crimes praticados.

Sob o prisma do equilíbrio e da eficiência, há ganhos estratégicos para as duas partes e uma maximização dos ganhos mútuos. Cumpre ressaltar que o acordo traz custos menores ao Estado do que aqueles decorrentes da investigação e da punição, ainda que limitada à esfera administrativa. Aliás, no processo judicial não há garantia de punição. Ou seja, evitam-se os altíssimos gastos com o devido processo legal sem a certeza de punir aquele que pratica o ilícito. E a leniência, ainda, ocorre sem eximir a necessidade de reparação do dano.

Nesse ponto, asseveram Ferreira Filho e Amaral (2018, p. 859): 
Para afastar a impunibilidade e a manutenção das práticas corruptivas, é fundamental olhar a norma pela ótica do Teorema de Coase e da Teoria dos Jogos, assegurando custos que os custos de barganha nas transações à margem do sistema legal, sempre importem em prejuízo econômico frente às condutas éticas e valoração das políticas de Compliance.

Destaque-se, contudo, e sob a lógica da Teoria dos Jogos, que um dos requisitos é justamente a exigência de que a pessoa jurídica seja a primeira a se manifestar sobre seu interesse em cooperar para apuração do ato ilícito, além de conduzir à identificação dos demais envolvidos, bem como provas a respeito. Pretende o dispositivo, nesse ponto, estimular a celebração ágil do acordo, de forma que um dos envolvidos apresente receio de que os outros façam antes de si, impossibilitando a sua ação defensiva.

O dilema do prisioneiro, repise-se, desenvolvido por Merrill Flood e Melvin Dresher e adaptado por Albert W. Tucker, lida com o conflito de interesses entre dois prisioneiros, presos por um crime brando, embora suspeitos de um crime grave. Diante do interrogatório individual, sobreleva uma escolha para cada, sem ter consciência daquela que será feita pelo outro. Cada qual terá duas opções: a) entregar o comparsa, a fim de incriminá-lo pelo crime mais grave; b) restar calado. Se um denunciar e o outro calar, quem denunciou terá liberdade e quem calou a pena máxima. Se os dois ficam em silêncio, ambos recebem a pena pelo crime mais brando. Se ambos denunciam, ambos serão punidos com uma pena intermediária (Pereira, 2008, p. 10):

Formalizando essa situação com os ganhos de cada jogador, temos as seguintes possibilidades: se ambos cooperarem, recebem R (recompensa); se ambos desertarem, recebem $P$ (punição); se tiverem atitudes antagônicas, o cooperador recebe S ("tolo", do inglês sucker) e o desertor recebe T (tentação). A Tab. 2.1 mostra os ganhos do DP: 


\begin{tabular}{l|c|c|c}
\cline { 3 - 4 } \multicolumn{2}{c|}{} & \multicolumn{2}{c}{ Jogador $B$} \\
\cline { 3 - 4 } \multicolumn{2}{c|}{} & Coopera & Deserta \\
\hline \multirow{2}{*}{ Jogador $A$} & Coopera & $(\mathrm{R}, \mathrm{R})$ & $(\mathrm{S}, \mathrm{T})$ \\
\cline { 2 - 4 } & Deserta & $(\mathrm{T}, \mathrm{S})$ & $(\mathrm{P}, \mathrm{P})$ \\
\hline
\end{tabular}

Sobre esta perspectiva, John Nash edificou o seu equilíbrio a partir da "estratégia dominante". Isto é, a situação em que o competidor obtém o melhor resultado independentemente da escolha alheia. Noutras palavras, o "equilíbrio de Nash" resulta da obtenção do melhor resultado que o jogador pode obter unilateralmente. Nesta situação, a dupla traição, ou delação, representa a situação de equilíbrio, uma vez que acarreta benefícios a ambos de forma independente da atitude alheia.

Segundo Nash, um ponto de equilíbrio (ou equilíbrio de Nash), é o conjunto de resultados opostos que maximiza os ganhos de cada jogador em face da melhor estratégia do outro, ou seja, o encontro das estratégias ótimas de cada jogador com as dos adversários. É uma combinação das estratégias dos jogadores na qual nenhum jogador pode ao mudar de estratégia, aumentar seus ganhos sem alterar também o ganho de seu adversário. Mas isso não implica que a situação resultante das decisões conjuntas dos jogadores seja a melhor possível. Contudo, a dominância e a perfeição deste ponto de equilíbrio espantam a todos que se defrontam com este quadro pela primeira vez (Pereira, 2008, p. 10).

A propósito, deve-se ter em mente, enquanto um elemento fundante, que o princípio da eficiência é a base para o combate à corrupção, e, aqui, retomamos a análise econômica do direito. É necessário que a celebração do acordo seja mais vantajosa do que a continuidade delitiva também do ponto de vista econômico. Noutras palavras, com a celebração do acordo, não incidem as pesadas penalidades em relação ao já praticado e, como consequência, ao cessar o ilícito, não há a geração de riscos de passivos para o futuro. 
Cumpre lembrar, sob a lógica da AED, as palavras de Coase (2017, p. 115):

Um determinado arranjo de direitos pode propiciar um valor de produção maior do que qualquer outro. Mas, a menos que este seja o arranjo de direitos estabelecido pelo sistema jurídico, os custos para atingir os mesmos resultados através da alteração e combinação de direitos por meio do mercado podem ser tão elevados que este arranjo ótimo dos direitos, bem como o maior valor de produção que ele traria, pode nunca ser alcançado.

Especificamente sobre a temática abordada nesse texto:

A lei 12.847/2013, chamada de lei anticorrupção, fincada no tripé da responsabilidade objetiva das pessoas jurídicas, direcionamento das pessoas jurídicas à adoção de mecanismos internos de integridade (compliance), e possibilidade de acordos de leniência, tem potencial para colaborar, sob a perspectiva de uma atuação estatal mais eficiente, no combate a corrupção e à improbidade administrativa, consideradas as condutas típicas da mesma lei como lesivas à Administração Pública nacional ou estrangeira (Machado, 2017, p. 168).

Ainda:

De modo que homenageia o princípio da eficiência a introdução (inclusive com base na efetividade já observada no direito comparado) de mecanismos de prevenção e apuração de tais ilícitos, que drenam recursos públicos para interesses privados, causando prejuízos à sociedade e ao cumprimento pelo Estado dos objetivos pactuados no texto constitucional. O acordo de leniência como técnica especial de investigação apresenta-se como mecanismo com essa capacidade (Machado, 2017, p. 179). 
Ferreira Filho e Amaral (2018, p. 856), no entanto, apresentam certas críticas ao modelo:

No que se refere ao à Lei 12.846/2013, seria mais eficiente para a empresa seguir o conjunto normativo imposto, refletindo a premissa de que "a lei é desnecessária e indesejável onde a negociação é bem-sucedida, e que a lei é necessária e desejável onde a negociação não dá certo" (COASE, 2008, p. 12). Contudo, as benesses do acordo de leniência, e sua forma de aplicação, começam a apresentar determinados custos de barganha que, na conta rasa do lucro puro, à margem da ética e da moral, podem tornar-se tentadores aos interesses escusos de determinadas empresas.

É de se salientar, contudo, que a suavização das sanções tem como escopo justamente possibilitar a celebração do acordo para se atingir outras finalidades maiores, como a satisfação do resultado investigativo e o ressarcimento dos cofres públicos, a fim de que, dessa forma, outros objetivos previstos na Carta Maior possam ser atingidos. Noutras palavras, a celebração do acordo de leniência possibilita, de maneira indireta, a realização de direitos que se voltam para a proteção da dignidade humana.

Com maior detalhamento, nos termos do artigo $6^{\circ}$ da Lei Anticorrupção, na esfera administrativa, aplicam-se duas penalidades: a) multa entre 0,1\% (um décimo por cento) e $20 \%$ (vinte por cento) do faturamento bruto do exercício anterior à instauração do processo administrativo, nunca menor que a vantagem auferida, quando possível de ser estimada, ou multa entre $\mathrm{R} \$ 6.000,00$ (seis mil reais) e $R \$ 60.000 .000,00$ (sessenta milhões de reais), quando não puder ser utilizado o critério do faturamento bruto; b) publicação extraordinária de decisão condenatória (name and shame), às custas da pessoa jurídica, em jornal de grande circulação na área de atuação da pessoa jurídica ou de circulação nacional, assim como edital, por no mínimo trinta dias, no estabelecimento ou local de atividade, visível ao público, e na internet. 
Já na esfera cível, as sanções são previstas no artigo 19 da lei: a) perdimento de bens, direitos ou valores decorrentes da vantagem ilícita; b) suspensão ou interdição parcial das atividades; c) dissolução compulsória da pessoa jurídica; d) proibição de receber incentivos, subsídios, subvenções, doações ou empréstimos de órgãos ou entidades públicas e de instituições financeiras públicas ou controladas pelo poder público, pelo prazo mínimo de 1 (um) e máximo de 5 (cinco) anos.

Conforme o artigo 16, $\S 2^{\circ}$, da Lei Anticorrupção, em caso de celebração do acordo de leniência, embora os efeitos sejam, em regra, na esfera administrativa, eles também atingem a esfera judicial.

Primeiramente, no âmbito administrativo, a pessoa jurídica estará isenta do name and shame (publicação da decisão condenatória). E, mais importante, haverá uma redução de até dois terços da multa aplicável, o que, como dito, não exime a obrigação de reparar o dano. Já no âmbito judicial, a celebração do acordo de leniência isenta a empresa da proibição de receber incentivos, subsídios, subvenções, doações ou empréstimos de órgãos, entidades públicas ou instituições financeiras controladas pelo Poder Público.

Nota-se que, para o acordante, a celebração traz benefícios econômicos de larga monta, ao mesmo tempo em que, ao fazer cessar o ilícito, diminui os riscos e estimula a cultura de compliance.

Outrossim, conforme entendimento da Controladoria-Geral da União (2019), a empresa que compactuar com o acordo deverá, entre outros:

Declarar ostensivamente o compromisso institucional com o programa de integridade e com o combate a atos de corrupção e fraude. Atuar em ações coletivas voltadas para a discussão de boas práticas de integridade. Adotar procedimentos e controles de verificação de conformidade de terceiros com relação à aplicação de código de conduta. Criar treinamentos específicos para empregados que atuem na contratação de terceiros, na verificação prévia a doações filantrópicas e patrocínios e em processos licitatórios. Revisar processos e fluxos internos visando a adoção de medidas 
mitigatórias à prática de irregularidades. Controlar a efetivação de pagamentos decorrentes de contratos com fornecedores com alto grau de risco de prática de atos lesivos (em virtude do contato com a administração pública). Aprimorar controles e procedimentos voltados à prevenção de atos lesivos durante o contato com a administração pública como, por exemplo, procedimentos licitatórios e execução de contratos administrativos. Elaborar regra sobre comunicação de irregularidades ou atos ilícitos às autoridades governamentais. Envolver a área responsável pelo programa de integridade nas atividades de maior risco, como, por exemplo, due diligence de fornecedores e parceiros comerciais e oferecimento de brindes e presentes. Ampliar os itens questionados/avaliados em verificações prévias a contratação de terceiros. Definir e aplicar controles e procedimentos de supervisão de parceiros comerciais e fornecedores. Aditar contratos para a inclusão de cláusula anticorrupção, com menção expressa à Lei Anticorrupção ( $n^{\circ}$ 12.846/13). Analisar a idoneidade e o histórico de instituições candidatas a receber doações ou patrocínios. Divulgar na página da empresa na internet as doações, contribuições e patrocínio realizados ao longo do ano.

Nesse diapasão, o acordo de leniência abre caminho para o Estado avançar nas investigações e punir os agentes envolvidos nos atos ilícitos, de forma mais rápida e eficiente, possibilitando o retorno dos recursos públicos para os investimentos em políticas públicas. Mas, não se olvide, ao mesmo tempo, que o acordo traz benefícios econômicos e estratégicos para as pessoas jurídicas, evitando custos ainda maiores que decorreriam dos processos administrativos em caso de infração à lei, bem como de eventual processo judicial. No mais, é diminuído o risco de ilícitos futuros.

\section{OS ACORDOS DE LENIÊNCIA DECORRENTES DA OPERAÇÃO LAVA JATO}


Conforme informação veiculada pela Controladoria-Geral da União (2020), apenas nos sete primeiros meses de 2019, os acordos de leniência firmados pela CGU, com apoio da Advocacia-Geral da União, garantiram a recuperação de $\mathrm{R} \$ 1,5$ bilhão em ativos, revelando, ainda que resumidamente, considerável reembolso econômico para o Estado:

Ao todo, nove acordos de leniência já foram firmados com empresas como Andrade Gutierrez, Odebrecht, Braskem e SBM Offshore. Parte das negociações envolvem condutas investigadas pela Operação Lava-Jato. Outros 22 acordos de leniência estão em andamento. Os valores a serem ressarcidos envolvem pagamentos de multa, dano e enriquecimento ilícito. Com os nove acordos já assinados, o retorno de recursos ao erário será de $\mathrm{R} \$$ 11,15 bilhões nos próximos anos, dos quais $\mathrm{R} \$ 3,1$ bilhões já foram recuperados.

A propósito, conforme atualização realizada em dezembro de 2019, a Controladoria-Geral da União (2019) publicou Balanço e Monitoramento, explicitando menção nos seguintes termos:

Até o momento, a CGU, em conjunto com a Advocacia-Geral da União (AGU), assinou onze acordos de leniência com empresas investigadas pela prática dos atos lesivos previstos na Lei Anticorrupção ( $n^{\circ}$ 12.846/2013) e dos ilícitos administrativos previstos na Lei de Licitações ( $n^{\circ}$ 8.666/1993). Os valores a serem ressarcidos envolvem os pagamentos de multa, dano e enriquecimento ilícito. O retorno de recursos aos cofres públicos atingiu a marca de R\$ 13,67 bilhões. Outros 22 acordos de leniência estão em andamento.

De acordo com o portal da CGU (2019), tais valores, consoante a balanço de dezembro de 2019, dizem respeito aos acordos celebrados com as seguintes empresas: SBM Offshore, OAS, Nova Participações S/A, Bilfinger, UTC Participações S/A, Camargo Corrêa, Mullenlowe e FCB Brasil, Andrade Gutierrez, Odebrecht, 
Braskem S/A, Technip Brasil e Flexibras, resultando acordos cujo valor total foi de R\$ 13.671.855.155,97 (treze bilhões, seiscentos e setenta e um milhões, oitocentos e cinquenta e cinco mil, cento e cinquenta e cinco reais e noventa e sete centavos), dos quais já foram pagos $\mathrm{R} \$ 3.612 .366 .457,76$ (três bilhões, seiscentos e doze milhões, trezentos e sessenta e seis mil, quatrocentos e cinquenta e sete reais e setenta e seis centavos), conforme Tabela 1 abaixo:

\section{Tabela 1}

Valores atualizados referente reembolso aos cofres públicos até junho de 2020.

\begin{tabular}{lrr}
\hline \multicolumn{1}{c}{ Empresa } & \multicolumn{1}{c}{ Valor ajustado } & \multicolumn{1}{c}{ Valor pago } \\
\hline SBM Offshore & $\mathrm{R} \$ 1.286 .038 .200,00$ & $\mathrm{R} \$ 751.096 .652,29$ \\
OAS & $\mathrm{R} \$ 1.929 .257 .982,37$ & \\
Nova Participações & $\mathrm{R} \$ 516.301 .313,70$ & $\mathrm{R} \$ 1.523 .329,27$ \\
S/A & & $\mathrm{R} \$ 11.036 .345,49$ \\
Bilfinger & $\mathrm{R} \$ 11.036 .345,49$ & $\mathrm{R} \$ 36.600 .038,93$ \\
UTC Participações S/A & $\mathrm{R} \$ 1774.658 .165,21$ & $\mathrm{R} \$ 377.919 .910,34$ \\
Camargo Corrêa & $\mathrm{R} \$ 50.000 .000,00$ & $\mathrm{R} \$ 53.985 .613,81$ \\
Mullenlowe e FCB & $\mathrm{R} \$ 1.489 .361 .135,28$ & $\mathrm{R} \$ 375.783 .802,90$ \\
Brasil & $\mathrm{R} \$ 2.727 .239 .997,64$ & $\mathrm{R} \$ 113 . .921 .523,70$ \\
Andrade Gutierrez & $\mathrm{R} \$ 2.872 .038 .787,73$ & $\mathrm{R} \$ 1.577 .419 .819,20$ \\
Odebrecht & $\mathrm{R} \$ 819.794 .768,79$ & $\mathrm{R} \$ 313.079 .412,83$ \\
Braskem S/A & $\mathrm{R} \$ 13.671 .855 .155,97$ & $\mathrm{R} \$ 3.612 .366 .457,76$ \\
Technip Brasil e & &
\end{tabular}

Fonte: CGU (2019)

Saliente-se que, embora alguns termos específicos dos acordos sejam restritos, os próprios acordos - em sua maior parcela - e os dados acima indicados são publicados no próprio sítio eletrônico da Controladoria-Geral da União (2019). Ademais, deve-se ressaltar que embora os termos dos acordos atinjam cifras 
superiores a $R \$ 13$ bilhões, há um ajuste parcelado de pagamentos, sendo que até a data da atualização da tabela o valor efetivamente devolvido era pouco maior do que $\mathrm{R} \$ 3,5$ bilhões.

Deve-se ter em mente que a publicação dos termos dos acordos, a despeito de algumas informações tarjadas, homenageia o princípio da ampla publicidade e da transparência, inscrito no artigo $5^{\circ}, X X X I I I, C F$, o qual excepciona o sigilo apenas para informações imprescindíveis à segurança da sociedade e do Estado. Nesse ponto, como realçado pela CGU (2019), existe um enquadramento no artigo 23, VIII, da Lei de Acesso à Informação, a qual considera dentro da excepcionalidade as informações cujo acesso irrestrito possa "comprometer atividades de inteligência, bem como de investigação ou fiscalização em andamento, relacionadas com a prevenção ou repressão de infrações".

Ademais, consoante o $\$ 6^{\circ}$ do artigo 16 da Lei Anticorrupção, a "proposta de acordo de leniência somente se tornará pública após a efetivação do respectivo acordo, salvo no interesse das investigações e do processo administrativo". De forma que o artigo 39, parágrafo único, do Decreto $n^{\circ} 8.420 / 2015$ determina que a CGU mantenha "restrito o acesso aos documentos e informações comercialmente sensíveis da pessoa jurídica signatária do acordo de leniência".

Não se olvide, ainda, que a própria Lei de Acesso à Informação prevê a necessidade de respeito e restrições a informações que digam respeito à intimidade, vida privada, honra e imagem das pessoas e liberdades e garantias individuais (art. 31), em consonância com a proteção constitucional.

Daí a razão de que, a despeito da transparência e publicidade que devem direcionar os termos dos acordos celebrados, alguns dados devem ser mantidos de forma restrita, tendo a Lei de Acesso à Informação se adequado ao mandamento constitucional. Frise-se, por oportuno, que no presente estudo são utilizadas exclusivamente informações veiculadas publicamente, de forma objetiva, sem quaisquer apontamentos éticos às condutas específicas que motivaram a celebração do acordo sob estudo. 


\section{OS ACORDOS DE LENIÊNCIA CELEBRADOS NO ÂMBITO DO ANEL DE INTEGRAÇÃO E DA OPERAÇÃO INTEGRAÇÃO}

O Anel de Integração fora criado em 1997 e estabelece interligações entre as principais cidades do Paraná, como Foz do Iguaçu, Maringá, Londrina, Ponta Grossa, Curitiba e Paranaguá. Dividido em seis lotes de concessão engloba cinco rodovias federais: BR-376, BR- 369, BR-153, BR-373 e BR-277, além de rodovias estaduais, como a PR-151, totalizando 2,4 mil quilômetros. A concessão dos lotes se deu por um prazo de 24 anos, encerrando-se em 2021. Após decisão judicial em 2016 impedindo as renovações, houve aprovação da Lei n 13.448/2017, que passou a impedir que os contratos do Anel de Integração fossem renovados automaticamente, sendo necessária a realização de nova licitação.

Como se percebe pelo mapa abaixo (SINTRACOOSUL, 2020), o Anel de Integração tem seus lotes divididos entre seis concessionárias: Viapar, Ecocataratas, Econorte, Rodonorte, Caminhos do Paraná e Ecovia.

\section{Figura 1}

Mapa do Anel de Integração paranaense com respectivas concessionárias.

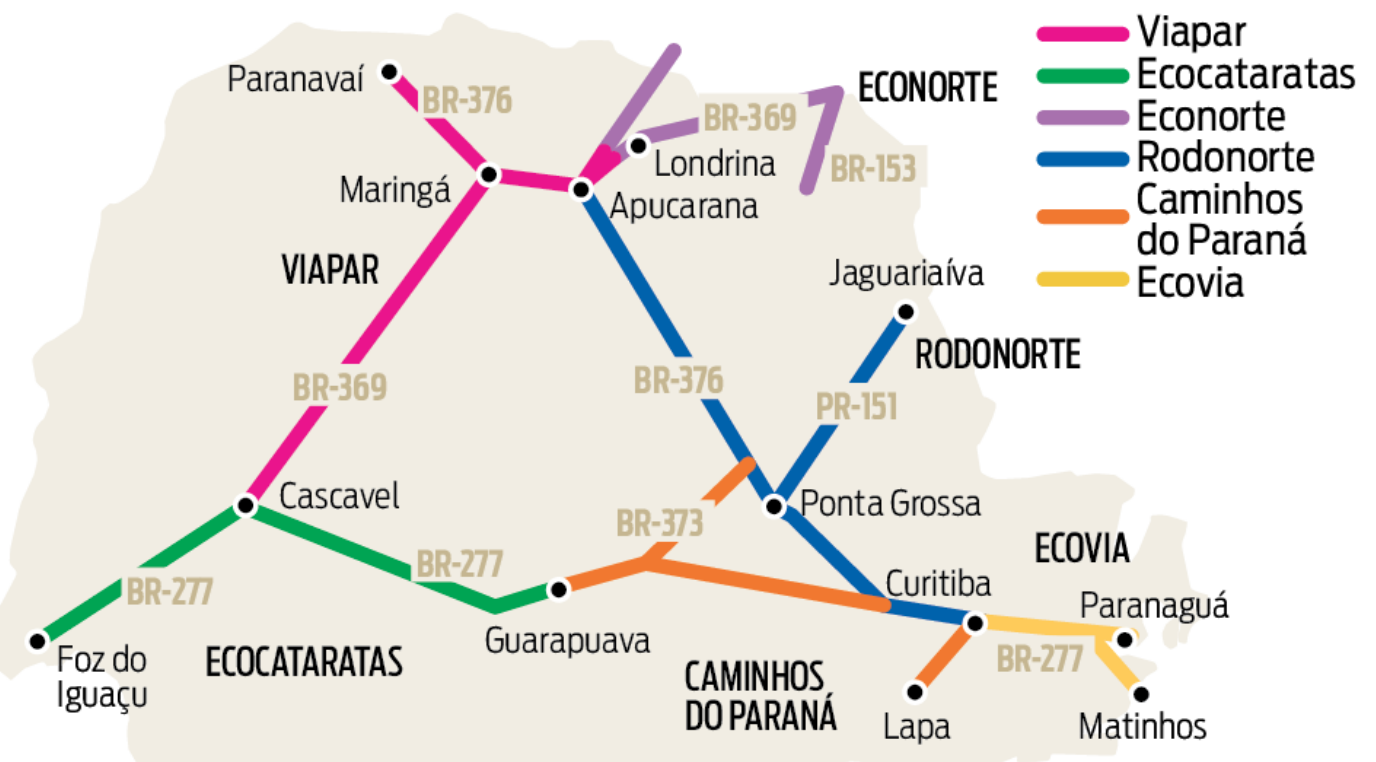


Nesse contexto, em fevereiro de 2018, foi deflagrada a Operação Integração II, a $55^{a}$ fase da Operação Lava Jato. Conforme informado pelo Ministério Público Federal, nesta fase foram realizadas 19 prisões e cumpridos 73 mandados de buscas e apreensões. Ainda, explana o MPF (2020):

Fase foi deflagrada para aprofundar as investigações sobre a prática de crimes de corrupção, lavagem de dinheiro, sonegação fiscal, estelionato e peculato em esquema relacionado à administração das rodovias federais no Paraná. Os alvos das medidas são as seis concessionárias que administram o Anel de Integração do Paraná: Econorte, Ecovia, Ecocataratas, Rodonorte, Viapar e Caminhos do Paraná, além de intermediadores e agentes públicos corrompidos beneficiários do esquema.

De acordo com o Ministério Público Federal (2019), os mandados de prisão preventiva e temporária e de busca e apreensão foram expedidos pela $23^{a}$ Vara Federal de Curitiba e cumpridos em cidades do Paraná, São Paulo, Santa Catarina e Rio de Janeiro.

Conforme narra o MPF (2019), foram identificados dois esquemas de pagamento de propinas delatados pelos colaboradores, os quais, juntos, teriam redundado em pagamentos indevidos na ordem de $\mathrm{R} \$ 55$ milhões, envolvendo funcionários e agentes do Departamento de Estradas de Rodagem do Paraná (DER/PR), de seis concessionárias, da Associação Brasileira de Concessões Rodoviárias (ABCR), da Agência Reguladora do Paraná (Agepar), da Assembleia Legislativa do Estado e do Tribunal de Contas do Estado.

Além das questões criminais, destaque-se que as condutas são consideradas ilícitas nos termos do artigo $5^{\circ}$ da Lei Anticorrupção, em especial "prometer, oferecer ou dar, direta ou indiretamente, vantagem indevida a agente público, ou a terceira pessoa a ele relacionada", fraudar licitações e "dificultar atividade de investigação ou fiscalização de órgãos, entidades ou agentes públicos, ou intervir em sua atuação, inclusive no âmbito das agências reguladoras e dos órgãos de fiscalização do sistema financeiro nacional". 
No tocante às irregularidades nos aditivos contratuais, o MPF (2019) ressaltou os pontos salientados em auditoria do Tribunal de Contas da União:

Conforme a corte de Contas: 1) embora os investimentos previstos no contrato original tenham sido remanejados para os últimos anos das concessões, sem quaisquer justificativas técnicas, desconectados das necessidades dos usuários dos trechos rodoviários atingidos, os valores originalmente previstos para restauração, recuperação e manutenção dessas obras não executadas permaneceram incorporadas às tarifas de pedágio cobradas dos usuários, portanto o usuário pagou por um serviço que não foi executado; 2) a alteração do critério de medição dos serviços realizados de "área estimada" para "quantitativo de insumos" tornou a fiscalização menos eficaz e facilitou a utilização de materiais de baixa qualidade, que exigem maiores gastos com manutenção, em benefício das concessionárias, eliminando assim o risco de execução assumido no contrato original; 3) a ocorrência de significativas mudanças nos cenários econômicos, desde a época em que foram assinados os contratos, que impactaram o custo do capital, eventualmente desonerando as concessionárias, não foram consideradas nos ajustes promovidos, de modo a reduzir proporcionalmente as tarifas cobradas dos usuários; ao contrário, há indícios de que o fluxo de caixa alterou-se em prol das concessionárias mesmo levando-se em conta, na avaliação dos investimentos, o custo de oportunidade da época em que os contratos foram assinados.

Em consequência deste contexto, a Ecorodovias celebrou acordo de leniência' com o Ministério Público Federal, no âmbito da Força-Tarefa Lava Jato, o qual foi homologado em 19 de setembro de 2019. Pelo acordo, seis praças de pedágio, sob concessão da Ecovia e da Ecocataratas, teriam uma redução de tarifa de 30\% (trinta por cento): São José dos Pinhais, na Região de Curitiba; Candói, na

\footnotetext{
' Disponível em: http://www.mpf.mp.br/pr/sala-de-imprensa/docs/acordo-leniencia-ecorodovias-1.pdf.
} 
região central; Laranjeiras do Sul, na região central; Cascavel, no Oeste; Céu Azul, no Oeste; São Miguel do Iguaçu, no Oeste.

De acordo com a Cláusula $4^{\mathrm{a}}$ do acordo:

Cláusula $4^{\mathrm{a}}$. Essas apurações estão relacionadas à atuação das COLABORADORAS, por si ou por demais empresas integrantes de seu grupo econômico, em práticas de corrupção, fraudes tributárias e lavagem de dinheiro, dentre outras, relacionadas direta ou indiretamente aos contratos de concessão de obras públicas de ns. 73/97 e 76/97, firmados entre o Estado do Paraná, o Departamento de Estradas e Rodagens do Paraná ("DER/PR"), o Departamento Nacional de Estradas e Rodagem ("DNER"), o Ministério do Transportes e as COLABORADORAS, seus aditivos, suas alterações por atos administrativos e sua fiscalização.

Parágrafo único. As COLABORADORAS reconhecem o pagamento de propinas para a obtenção dos atos administrativos mencionados nos citados anexos, dentro outros fatos constantes nos anexos a este Acordo.

Ademais, conforme a Cláusula $5^{\mathrm{a}}$, as empresas concordariam em levar ao conhecimento do STF fatos e provas para auxiliar nas investigações descritas, inclusive comprometendo-se em apresentar uma descrição detalhada dos fatos, com papéis dos agentes envolvidos e envolvimento das colaboradoras, documentos, informações e materiais relevantes, bem como cessar completamente o envolvimento nos atos ilícitos apurados e adotar medidas de compliance, como se observa no Apêndice 1 (Cláusula 6ª).

Além disso, nos termos do acordo, as concessionárias deveriam reconhecer publicamente, em placas espalhadas nas praças de pedágio, radiodifusão e mídia impressa, o erro e a informação da existência do acordo junto à reparação da sociedade paranaense em multa decorrente da redução de 30\% das tarifas, por pelo menos doze meses, além de outras compensações. E no cupom da tarifa, deveria ser inserto o seguinte texto: "O valor do pedágio foi reduzido em 30\% 
porque recursos provenientes de corrupção foram recuperados pelo MPF e aplicados em benefício do usuário".

Consoante termos do acordo, houve incidência de duas multas às colaboradoras: a) R\$370 milhões para reparação de danos das infrações e ilícitos; b) $\mathrm{R} \$ 30$ milhões nos termos do artigo 12 da Lei de Improbidade Administrativa, a ser revertido integralmente ao Estado do Paraná.

Quanto à primeira multa, o importe de $\mathrm{R} \$ 220$ milhões adviria do desconto de 30\% (trinta por cento) da tarifa em favor dos usuários em todos os pedágios operados pelas empresas, sendo $\mathrm{R} \$ 120$ milhões decorrentes do trecho operado pela Ecocataratas e R\$100 milhões do trecho da Ecovia, "tendo em conta a extensão das obras suprimidas e dos trechos rodoviários administrados, o faturamento das empresas, o impacto tarifário, o montante de propinas pagas e as vantagens obtidas" (termos do acordo). O desconto perduraria até se atingir as referidas cifras.

Quanto aos demais $\mathrm{R} \$ 150$ milhões referentes à reparação de danos, deve referido valor ser utilizado "para a execução de obras nas rodovias a elas concedidas, constantes no Programa de Exploração da Rodovia - PER original ou que sejam consideradas prioritárias atualmente conforme justificativa técnica do DER/PR", não se englobando as obras às quais já estariam obrigadas por contrato. Tal investimento seria rateado da seguinte forma: a) $R \$ 130$ milhões no trecho administrado pela Ecocataratas; b) $\mathrm{R} \$ 20$ milhões no trecho administrativo pela Ecovia.

Havendo saldo ao final da concessão para ser pago, deveria o mesmo ser depositado em favor do Fundo de Direitos Difusos do Estado do Paraná, ou, caso inexistente, em favor do próprio Estado (Parágrafo 18 da Cláusula 6ª).

Pois bem.

Em primeiro lugar, insta ressaltar que a questão não é imune de críticas. Como se nota pelo artigo 16, §10, da LAE, a atribuição para celebrar acordo de leniência no âmbito da Lei Anticorrupção quanto a atos ilícitos em face da União é da Controladoria-Geral da União, não havendo legitimação específica ao Ministério Público. 
A despeito disso, a $5^{\mathrm{a}}$ Câmara de Coordenação e Revisão - Combate à Corrupção do Ministério Público Federal editou a Orientação 7/2017, no entendimento de que a legitimidade para que o MPF celebre o acordo de leniência encontra-se prevista no artigo 129, inciso I, CF; art. 5 $5^{\circ} 6^{\circ}$, da Lei n 7.347/85; art. 26 da Convenção de Palermo; art. 37 da Convenção de Mérida; artigos $3^{\circ}$, $\S 2^{\circ}$ e $\S 3^{\circ}$, do Código de Processo Civil, artigos 840 e 932, inciso III, do Código Civil, artigos 16 a 21 da Lei $n^{\circ} 12.846 / 2013$; e na Lei $n^{\circ} 13.140 / 2015$.

Grosso modo, a legitimidade estaria estampada na teoria dos poderes implícitos, a partir do artigo 129, IX, CF, que permite ao Ministério Público "exercer outras funções que the forem conferidas, desde que compatíveis com sua finalidade", inclusive com julgamento tangente do STF:

[...] é princípio basilar da hermenêutica constitucional o dos "poderes implícitos", segundo o qual, quando a Constituição Federal concede os fins, dá os meios. Se a atividade fim - promoção da ação penal pública - foi outorgada ao parquet em foro de privatividade, não se concebe como não Ihe oportunizar a colheita de prova para tanto, já que o CPP autoriza que "peças de informação" embasem a denúncia. (RE 441004/PR, Rel. Joaquim Barbosa, j. 17.12.2009).

Embora haja esse entendimento, o Tribunal Regional Federal da $4^{\mathrm{a}}$ Região, no julgamento do Agravo de Instrumento 5023972-66.2017.4.04.0000, em 22 de agosto de 2017, asseverou que os acordos de leniência celebrados pelo Ministério Público Federal apenas possuiriam validade se ratificados pela Controladoria-Geral da União, justamente em face da legitimidade específica que esta detém nos termos legais:

10. A autoridade competente para firmar o acordo de leniência, no âmbito do Poder Executivo Federal é a Controladoria Geral da União (CGU).

11. Não há impedimentos para que haja a participação de outros órgãos da administração pública federal no acordo de leniência como a Advocacia 
Geral da União, o Ministério Público Federal e o Tribunal de Contas da União, havendo, portanto, a necessidade de uma atuação harmônica e cooperativa desses referidos entes públicos.

12. O acordo de leniência firmado pelo Grupo Odebrecht no âmbito administrativo necessita ser re-ratificado pelo ente competente, com participação dos demais entes, levando-se em conta o ressarcimento ao erário e a multa, sob pena de não ensejar efeitos jurídicos válidos.

13. Enquanto não houver a re-ratificação do acordo de leniência, a empresa deverá permanecer na ação de improbidade, persistindo o interesse no bloqueio dos bens, não porque o MP não pode transacionar sobre as penas, mas porque o referido acordo possui vícios que precisam ser sanados para que resulte íntegra sua validade, gerando os efeitos previstos naquele ato negocial. (TRF4, Agravo de Instrumento 5023972-66.2017.4.04.0000, Rel. Des. Vânia Hack de Almeida).

Além disso, deve-se frisar que o acordo de leniência no âmbito da Lei Anticorrupção deve estar atento a todos os requisitos e benefícios dispostos no artigo 16 da LAE, já mencionados nesta exposição. Um dos benefícios é justamente a isenção da publicação extraordinária da decisão condenatória (art. $6^{\circ}$, inciso II), o que pode gerar questionamentos em face das mencionadas Cláusula 6a, " $n$ ", "o" e "p" do acordo firmado com a Ecorodovias, no qual houve a exigência de manifestação pública de reconhecimento do ilícito, por meio de placas em local público, rádio e jornal de grande circulação.

Apesar desses pontos, o acordo foi judicialmente homologado pela Justiça Federal em Curitiba em 19 de setembro de 2019 e já está sendo implementado.

Semelhante acordo de leniência foi celebrado com a concessionária Rodonorte, com pagamento de $\mathrm{R} \$ 715$ milhões a título de reparação de danos e $\mathrm{R} \$$ 35 milhões a título de multa prevista na Lei de Improbidade Administrativa. Da reparação de danos, $R \$ 350$ milhões decorreriam do desconto de 30\% (trinta por cento) na tarifa de pedágio e os demais $R \$ 365$ milhões seriam pagos com obras nos trechos concedidos. Assim como no acordo com a Ecorodovias, também 
deveria haver manifestação de pública de reconhecimento de ilícitos. Note-se que o acordo foi homologado em 23 de abril de 2019 pela $5^{a}$ Câmara de Coordenação e Revisão e passou a ser cumprido antes mesmo de homologação judicial².

Em setembro, de forma inédita, o MPF firmou acordo de leniência com empresa que participou lateralmente do esquema descrito na Operação Integração. A Puruña, que não se encontra entre as concessionárias, constituía empresa responsável por gerar caixa para que a Rodonorte realizasse pagamentos ilícitos. O acordo prevê o pagamento de $\mathrm{R} \$ 20$ milhões em obras e mais $\mathrm{R} \$ 500$ mil diretamente ao Estado do Paraná3.

Meio termo entre a leniência e a condenação judicial pode ser encontrado na opção da concessionária Caminhos do Paraná. Em 4 de maio de 2020, a $1^{\text {a }}$ Vara Federal de Curitiba condenou a concessionária Caminhos do Paraná, que não possui acordo de leniência fechado, nos Autos da Ação Civil Pública500253562.2019.4.04.0700, à devolução de $R \$ 150$ milhões aos cofres públicos, sendo metade nos primeiros doze meses. Nos termos da sentença, a própria concessionária havia apresentado um plano de devolução até o final da concessão, em outubro de 2021. Ademais, o valor de condenação decorreu de cálculos defendidos pela própria empresa, "considerando a diferença pelo que foi pago com o custo operacional e o dinheiro descontado pelo pagamento do Imposto de Renda e Contribuição Social", entre os anos de 2003 e 2018, e não apenas pelo total arrecadado na praça de pedágio da Lapa (Justiça Federal, 2020). Conforme informado pelo G1 Paraná (2020), a concessionária informou que cumpriria a decisão, o que já está fazendo a partir de conta específica destinada para tal fim.

Em outras Ações Civis Públicas movidas pelo Ministério Público Federal, o Tribunal Regional Federal da $4^{\mathrm{a}}$ Região determinou, nos Agravos de Instrumentos 5013724-70.2019.4.04.0000 e 5013034-41.2019.4.04.0000, a redução das tarifas nas praças de pedágio das concessionárias Caminhos do Paraná, em 25,77\% (vinte e cinco inteiros e setenta e sete décimos por cento), e Viapar, em 19,02\% (dezenove

\footnotetext{
2 Disponível em: http://www.mpf.mp.br/pr/sala-de-imprensa/docs/rodonorte.pdf.

3 Disponivel em: http://www.mpf.mp.br/atuacao-tematica/ccr5/coordenacao/colaboracoespremiadas-e-acordos-de-leniencia/doc_acordos_votos/Voto_PURUNA_1.25.000.003049-2019-16.pdf.
} 
inteiros e dois centésimos por cento), os quais corresponderiam aos degraus tarifários decorrentes de aditivos em que houve pagamento de propina a agentes públicos. As decisões, contudo, foram suspensas pelo Presidente do Superior Tribunal de Justiça, Min. João Otávio de Noronha, por entender que a redução drástica "restringe a capacidade financeira da empresa concessionária, comprometendo a continuidade dos serviços de manutenção, restauração e duplicação de trechos de rodovias sob sua responsabilidade e, com isso, colocando em risco a segurança dos usuários" (Suspensão de Liminar e de Sentença 2.511/PR e Suspensão de Liminar e de Sentença 2.513/PR, Min. João Otávio de Noronha, 28.06.2019). Observe-se que a decisão com concordância da Caminhos do Paraná adveio posteriormente a este julgado.

Em mesmo caminho, uma liminar da Justiça Federal em Curitiba, em Ação Civil Pública, havia determinado a desinstalação do pedágio de Jacarezinho, a redução da tarifa em outras praças em $26,75 \%$ (vinte e seis inteiros e setenta e cinco décimos por cento) e a retomada do cronograma original de obras, decisão mantida no Tribunal Regional Federal da $4^{a}$ Região (Agravo de Instrumento 5046437-35.2018.4.04.0000). A decisão, contudo, foi suspensa pelo Ministro João Otávio de Noronha, nos autos da Suspensão de Liminar e de Sentença 2.460/PR, em 26 de dezembro de 2018.

\section{A NECESSIDADE DE REEMBOLSO À SOCIEDADE E A ARGUIÇÃO DE DESCUMPRIMENTO DE PRECEITO FUNDAMENTAL $N^{\circ} 568$}

Consoante ressalta Harada (2019), em acordo bilionário celebrado pela Petrobras nos Estados Unidos, parte do dinheiro, especificamente $\mathrm{R} \$ 2,5$ bilhões, deveriam ser depositados em conta bancária do Ministério Público Federal em Curitiba. Metade do valor (R\$ 1,25 bilhão) seria destinado para "investimento social em projetos, iniciativas e desenvolvimento institucional de entidades e redes de entidades idôneas", devendo ser gerido por um fundo a ser criado por um "comitê de curadoria social".

A revelação trouxe consigo críticas doutrinárias: 
A toda evidência, o Ministério Público Federal que teria celebrado semelhante acordo investiu-se no poder de formular políticas públicas que nem o Presidente da República, eleito pelo voto popular, pode elaborar sem o respaldo dos representantes do povo no Congresso Nacional. Não se nega a idoneidade, a competência técnica e a seriedade dos componentes do nosso Ministério Público, mas, não cabe a um órgão ministerial imiscuir-se, não só na execução, como também, e principalmente na elaboração de políticas públicas (Harada, 2019).

Diante do fato, a Procuradora-Geral da República ingressou, em 12 de março de 2019, com uma Arguição de Descumprimento de Prefeito Fundamental, que recebeu o número 568. A ADPF alegava violação de preceito fundamental quanto à homologação do acordo entre a Petrobras e o Ministério Público, pela $13^{a}$ Vara Federal de Curitiba, nos autos 5002012-46.2019.1.00.0000.

Em consequência, requereu que os valores recuperados fossem destinados aos Estados, como transferência obrigatória, e fiscalizados pelo Tribunal de Contas da União.

Em 15 de março de 2019, o Relator da ADPF, Ministro Alexandre de Moraes, concedeu Medida Cautelar para suspender a decisão de homologação da $13^{a}$ Vara Federal de Curitiba:

Dessa maneira, em princípio, parece ter ocorrido ilegal desvirtuamento na execução do acordo realizado entre a Petrobras e o Department of Justice (DoJ)/Securities and Exchange Commision (SEC), que, primeira e discricionariamente, definiu os Procuradores da República do MPF do Paraná como as únicas autoridades brasileiras previstas no termo internacional, para, na sequência, em desrespeito ao Princípio do Juiz Natural, definir qual seria o juízo competente para a homologação do segundo acordo - $13^{\text {a }}$ Vara Criminal Federal de Curitiba -, e, por fim, estipulou cláusulas subjetivamente escolhidas 
pelas partes para destinação dos valores da multa e inexistentes no acordo original.

[...]

Diante de todo o exposto, CONCEDO A MEDIDA CAUTELAR postulada na presente ADPF, ad referendum do Plenário (art. $5^{\circ}, \S 7^{\circ}$, da Lei daquela Corte, com objeto semelhante. Cite-se a parte interessada nos autos da Rcl 33.667. À Secretaria para o traslado da presente decisão aos autos eletrônicos da Rcl 33.667 e para adoção de providências para a tramitação conjunta dos dois processos. Publique-se." 9.882/1999), para, com base no art. 5º $\S 3^{\circ}$, da Lei 9.882/1999:

(a) suspender todos os efeitos da decisão judicial proferida pelo Juízo da $13^{a}$ Vara Federal de Curitiba, que homologou o Acordo de Assunção de Obrigações firmado entre a Petrobras e os Procuradores da República do Ministério Público do Paraná (Força-Tarefa Lava-Jato), bem como a eficácia do próprio acordo;

(b) determinar o imediato bloqueio de todos os valores depositados pela Petrobras, bem como subsequentes rendimentos, na conta corrente designada pelo juízo da $13^{a}$ Vara Criminal Federal de Curitiba que, a partir desta decisão, deverão permanecer em depósito judicial vinculado ao mesmo Juízo, proibida qualquer movimentação de valores sem expressa decisão do SUPREMO TRIBUNAL FEDERAL;

(c) determinar a suspensão de todas as ações judiciais, em curso perante qualquer órgão ou Tribunal, ou que, eventualmente, venham a ser propostas e que tratem do objeto impugnado na presente ADPF;

(d) comunicar, com urgência, ao Juízo da $13^{a}$ Vara Criminal Federal de Curitiba, solicitando-lhe informações, no prazo de 10 (dez) dias, na forma do art. $6^{\circ}$ da Lei 9.882/1999;

(e) intimar todos os subscritores do acordo homologado perante a $13^{\text {a }}$ Vara Criminal Federal de Curitiba para a apresentação de informações, no prazo de 10 (dez) dias; 
(f) intimar a Câmara dos Deputados, a Advocacia-Geral da União, o Presidente da Petróleo Brasileiro S/A, para a apresentação de informações, no prazo comum de 10 (dez) dias;

(g) oficiar ao Tribunal de Contas da União, solicitando-Ihe informações sobre a eventual existência de procedimento no âmbito daquela Corte, com objeto semelhante.

Após a decisão, a Procuradora-Geral da República, o Presidente da Câmara dos Deputados, a União, representada pelo Advogado-Geral da União, com interveniência do Presidente do Senado Federal e do Procurador-Geral da Fazenda Nacional celebraram "Acordo sobre a Destinação de Valores", de modo que os valores percebidos em razão do acordo celebrado com as autoridades norte-americanas deveriam ser integralmente destinados ao Tesouro Nacional para serem aplicados em ações voltadas à educação e à proteção do meio ambiente, discriminadas no item 1 do referido Acordo. Em decisão de 17 de setembro de 2019, o Relator homologou o Acordo. Posteriormente, em 22 de março de 2020, houve ajuste no acordo, igualmente homologado, de forma a repassar parte da verba para o Ministério da Saúde para combate à pandemia de Covid-19.

Nota-se do Acordo homologado, a implícita compreensão de que as verbas decorrentes de reversão ao erário público em razão de acordos de leniência devem ser destinadas à efetivação de direitos fundamentais. No caso em questão, mais da metade da importância fora destinado para ações de educação, incluindo programas de educação infantil, Programa Criança Feliz, projetos de inovação tecnológica e ações socioeducativas em cooperação com os Estados. Outra parcela considerável do acordo original era destinada à Amazônia Legal, a incluir ações do Ministério da Defesa, do Ministério do Meio Ambiente, do IBAMA, do Ministério da Agricultura, Pecuária e Abastecimento e ações articuladas entre o Governo Federal e Estados da região amazônica. Posteriormente, com o ajuste do acordo, cerca de R 1 bilhão fora redirecionado ao Ministério da Saúde, "para o custeio das ações de prevenção, contenção, combate e mitigação à pandemia do coronavírus". 
A despeito de ser uma decisão apenas homologatória, é certo que as autoridades envolvidas souberam construir um acordo justamente no sentido de que se o prejuízo fora da sociedade, por ter ocorrido uma subtração de verbas para a satisfação de seus direitos, é para a sociedade, de forma direta, que devem retornar as verbas recuperadas.

Nesse ponto, a nosso ver, foram satisfatórios os termos dos acordos de leniência celebrados com as concessionárias do Anel de Integração, em especial quanto aos descontos nas tarifas de pedágio e as obras de melhoria, as quais beneficiam diretamente os cidadãos usuários do sistema. Ao mesmo tempo, incorporou benefícios ao próprio Estado, simplificando a persecução administrativa para fins de responsabilização e obtendo melhorias dos bens públicos. Assim como trouxe vantagens aos celebrantes, uma vez que propiciou-Ihe diminuição dos custos decorrentes da penalização. Economicamente, pode-se dizer, a equação alcançou um equilíbrio ótimo, sem que qualquer das partes se beneficiasse mais às custas das outras ou do dano causado.

\section{CONCLUSÃO}

À luz de todo o exposto, denotam-se importantes referenciais teóricos, os quais corroboram com a ideia da eficiência do acordo de leniência previsto pela Lei $n^{\circ} 12.846 / 13$. Posto que o princípio da eficiência é a base para o combate à corrupção, que justifica a existência e celebração de tal acordo por meio da referida Lei. E, além da diminuição na duração do processo ou aumento das condenações, os acordos de leniência possuem como principal objetivo a "mútua traição" entre os agentes corruptos, enfraquecendo suas relações. Como se nota, a suavização das sanções que se dão por meio do acordo de leniência tem como escopo possibilitar a sua celebração para se atingir finalidades maiores, como a satisfação do resultado investigativo e o ressarcimento dos cofres públicos, a fim de que, dessa forma, outros objetivos previstos na Carta Maior possam ser atingidos.

Por conseguinte, apesar de demonstrada a eficiência do acordo de leniência a partir dos ganhos estratégicos que proporciona às partes, coube ressaltar a sua 
relevância sob a ótica da análise econômica do direito (AED), uma vez que é necessário que a celebração do acordo de leniência seja algo mais vantajoso do que a continuidade delitiva também do ponto de vista econômico. Isso quer dizer que, ao deixar de incidir as pesadas penalidades em relação ao/s delito/s já praticado/s, o acordo de leniência faz garantir que cesse o ilícito, fazendo com que não sejam gerados riscos de passivos para o futuro. Portanto, sob a ótica da AED, destinada precipuamente à compreensão do comportamento dos indivíduos diante de uma norma jurídica e o resultado econômico desses comportamentos, observa-se que o acordo de leniência é um instituto que garante a eficiência do Estado como responsável pelo combate à corrupção e proporciona retornos econômicos por meio da sua celebração. Finalmente, aponta-se que a AED como método de abordagem da lei, que, de modo multidisciplinar, foi capaz de revelar indivíduos responsáveis por responderem aos devidos preceitos legais, através de modelos econômicos construídos sobre a presunção da racionalidade do comportamento humano, direcionando a análise dos resultados obtidos ao alcance do bem-estar social diante desse contexto complexo.

Ademais, a Lei Anticorrupção, na qual reside o instituto do acordo de leniência, supre uma lacuna no combate à corrupção em âmbito nacional ao penalizar não as pessoas naturais, mas as pessoas jurídicas pela prática de atos contra a administração pública, nacional ou estrangeira, conforme atos ilícitos descritos em seu teor. E, após analises acerca das aplicações fáticas dos acordos de leniência celebrados com as empresas concessionárias, ora pessoas jurídicas, no âmbito do Anel de Integração do Paraná e da Operação Integração, que ocorreu durante a $55^{a}$ fase da Operação Lava Jato,foi possível se observar, empiricamente, o fenômeno de que fatos análogos e geograficamente próximos motivaram a celebração de mais de um acordo, com empresas distintas.

Entretanto, cumpre frisar que, conforme o $\$ 10$ do dispositivo do acordo de leniência, no âmbito federal, a competência para sua celebração é da CGU, com apoio da AGU, conforme Portaria Conjunta CGU/AGU 2278/2016, mas, no caso em questão,tais acordos firmados partiram da discutível iniciativa do MPF. Sendo que o TRF da $4^{a}$ Região, no julgamento do Al 5023972-66.2017.4.04.0000, em 22 de 
agosto de 2017, asseverou que os acordos de leniência celebrados pelo MPF apenas possuiriam validade se ratificados pela CGU, justamente em face da legitimidade específica que esta detém nos termos legais. Ademais, destaca-se que, conforme o parágrafo $2^{\circ}$ do artigo 16 da LAE, a celebração do acordo de leniência isentará a pessoa jurídica da publicação extraordinária da decisão condenatória (na esfera administrativa), o que não ocorreu no acordo realizado pelo MPF com as empresas concessionárias do Anel de Integração do Paraná, que exigiu a manifestação pública de reconhecimento do ilícito via placas em local público, rádio e jornal de grande circulação.

Ainda nesse ínterim de condutas discutíveis e questionáveis, apresentou-se o acordo bilionário celebrado pela Petrobras nos Estados Unidos, no qual a destinação do dinheiro que havia sido acordada pelo MPF inicialmente foi alvo de Arguição de Descumprimento de Preceito Fundamental, ingressada pela Procuradoria-Geral da República, que recebeu o número 568. Após a decisão acerca da Arguição, a Procuradoria-Geral da República, juntamente com o Presidente da Câmara dos Deputados, a União, representada pelo AGU, com interveniência do Presidente do Senado Federal e do PGFN celebraram "Acordo sobre a Destinação de Valores", de modo que os valores percebidos em razão do acordo celebrado com as autoridades norte-americanas deveriam ser integralmente destinados ao Tesouro Nacional para serem aplicados em ações voltadas à educação e à proteção do meio ambiente, discriminadas no item 1 do referido Acordo. O Relator homologou o Acordo e, posteriormente, houve ajuste no referido acordo, igualmente homologado, de forma a repassar parte da verba para o Ministério da Saúde, no combate à pandemia de Covid-19.

Pode-se concluir a implícita compreensão de que as verbas decorrentes de reversão ao erário público em razão de acordos de leniência devem ser destinadas à efetivação de direitos fundamentais. Também pôde ser observado, nos casos dos acordos examinados firmados no Anel de Integração do Paraná, que o desconto na tarifa e a realização de obras de melhoria nos trechos administrados trazem benefícios diretos aos cidadãos usuários, beneficiando a sociedade que outrora fora prejudicada com os atos de desvios. E, apesar de existirem discussões acerca dos 
acordos celebrados, do ponto de vista da finalidade, há plena satisfação quanto aos benefícios sociais, o que coaduna com o pano de fundo da ADPF 568 e o Acordo realizado pelos entes públicos em seu encerramento.

Por fim, apesar de demonstradas as vantagens dos acordos de leniência, tanto de forma teórica quanto fática, e da sua representatividade sob o ponto de vista econômico e do ponto de vista estratégico, para as empresas celebrantes posto que o acordo de leniência abre caminho para o Estado no avanço das investigações e punição dos agentes envolvidos nos atos ilícitos, de forma mais rápida e eficiente, trazendo a possibilidade do retorno dos recursos públicos para os investimentos nas políticas públicas e, ao mesmo tempo, benefícios econômicos e estratégicos para as pessoas jurídicas, evitando custos ainda maiores que decorreriam dos processos administrativos em caso de infração à lei, bem como de eventual processo judicial, diminuindo o risco de ilícitos futuros - ressalta-se que o acordo de leniência deve ser desenvolvido de forma meticulosa de modo que os princípios, regras e normativas jurídicas não podem deixar de ser observadas em momento algum. Essa orientação se estabelece para os acordos de leniência de uma maneira geral, por possuir grande peso no âmbito econômico e demasiada visibilidade social positiva, sob pena de se prejudicar a imagem positiva acerca do acordo de leniência e, consequentemente, a vontade de firmá-lo por parte da pessoa jurídica que se encontrar em posição de fazê-lo, haja vista a imagem negativa repercutida pela insegurança jurídica gerada por tais inobservâncias.

\section{REFERÊNCIAS}

\section{Blum, U., Steinat, N. \& Veltins, M. (2008). On the rationale of leniency programs: a} game-theoretical analysis. European Journal of Law and Economics, 25(3), 209-229.

\section{Borges de Oliveira, E. A. \& Ceren, J. P. (2019). Lei Anticorrupção e Acordo de}


Borges de Oliveira, E. A. \& Payão, J. V. (2018). Direitos fundamentais na pósmodernidade sob a perspectiva da Análise Econômica do Direito. Revista da Faculdade Mineira de Direito, 21(41), 203-223.

Canetti, R. C. (2018). Acordo de leniência: fundamentos do instituto e os problemas de seus transplantes ao ordenamento jurídico brasileiro. Belo Horizonte: Fórum.

Carvalhosa, M. (2015). Considerações Sobre a Lei Anticorrupção das Pessoas Jurídicas: Lei 12.846/2013. São Paulo: Revista dos Tribunais.

Coase, R. H. (2017). A firma, o mercado e o direito. 2.ed. Rio de Janeiro: Forense.

Coelho, F. U. (1995). A Análise Econômica do Direito. Revista de Pós-Graduação em Direito da PUC, 2, 155-170.

Controladoria-Geral da União (2019). Acordo de leniência: vantagens. Disponível em: https://www.gov.br/cgu/pt-br/assuntos/responsabilizacao-deempresas/lei-anticorrupcao/acordo-leniencia/.

Controladoria-Geral da União (2020). Acordos de leniência celebrados pela CGU e AGU já garantiram o pagamento de R\$1,5 bilhão em 2019. Disponível em: https://www.gov.br/cgu/pt-br/assuntos/noticias/2019/08/acordos-deleniencia-celebrados-pela-cgu-e-agu-ja-garantiram-o-pagamento-de-r-1-5bilhao-em-2019.

Ferreira, A. C. \& Ferreira, P. C. A. (2017). Estudo Introdutório. In: Coase, R. H. A firma, o mercado e o direito. 2.ed. Rio de Janeiro: Forense, p. XI-LIX. 
Ferreira Filho, A. B. \& Amaral. A. C. C. Z. M. (2018). Análise Econômica do Acordo de Leniência na Lei Anticorrupção da Pessoa Jurídica. Revista Argumentum, 19(3), 845-861.

G1 Paraná (2020). Justiça determina que Caminhos do Paraná devolva R\$150 milhões arrecadados em praça de pedágio da Lapa. Disponível em: https://g1.globo.com/pr/parana/noticia/2020/05/04/justica-determina-quecaminhos-do-parana-devolva-r-150-milhoes-arrecadados-em-praca-depedagio-da-lapa.ghtml.

Harada, K. (2019). Destino dos recursos financeiros recuperados no âmbito da operação Lava Jato. Jus Navigandi.Disponível em: https://jus.com.br/artigos/72629/destino-dos-recursos-financeirosrecuperados-no-ambito-da-operacao-lava-jato.

Justiça Federal (2020). Caminhos do Paraná terá que devolver 150 milhões em tarifas arrecadadas em praça da Lapa. Disponível em: https://www.jfpr.jus.br/noticias/caminhos-do-parana-tera-que-devolver-150milhoes-em-tarifas-arrecadadas-em-praca-da-lapa/.

Machado, P. A. de O. (2017). Acordo de Leniência \& a Lei de Improbidade Administrativa. Curitiba: Juruá.

Ministério Público Federal (2019). Lava Jato: 19 pessoas têm a prisão decretada na 55a fase da operação. Disponível em: http://www.mpf.mp.br/pr/sala-deimprensa/noticias-pr/lava-jato-19-pessoas-tem-a-prisao-decretada-na-55afase-da-operacao.

Ministério Público Federal (2020). Lava Jato: entenda o caso. Disponível em: http://www.mpf.mp.br/grandes-casos/lava-jato/entenda-o-caso/lavajatotimeline-view. 
Pereira, M. A. (2008). Dilema do prisioneiro evolucionário darwiano e pavloviano no autômato celular unidimensional: uma nova representação e exploração exaustiva do espaço de parâmetros. Dissertação [Mestrado]. Faculdade de Filosofia, Ciências e Letras de Ribeirão Preto, Universidade de São Paulo, $195 f$.

Pinheiro, A. C. \& Saddi, J. (2005). Direito, economia e mercados. Rio de Janeiro: Elsevier.

Ribeiro, M. C. P. \& Klein, V. (2016). O que é Análise Econômica do Direito. 2. ed. Belo Horizonte: Fórum.

Sintracoosul, S. dos T. em C. da R. S. do P. (2020) Justiça impede governos estadual e federal de renovar contratos de pedágio no Paraná. Disponível em: http://www.sintracoosul.com.br/noticia/2415/justica-impede-governosestadual-e-federal-de-renovar-contratos-de-pedagio-no-parana.

'Emerson Ademir Borges de Oliveira: Universidade de Marília (UNIMAR), Programa de Pós-Graduação em Direito (PPGD), Marília, SP, Brasil.

iCelso Ferreira da Cruz Victoriano: Universidade de Marília (UNIMAR), Programa de Pós-Graduação em Direito (PPGD), Marília, SP, Brasil.

Data de submissão: 02/07/2020

Data de aprovação: 07/06/2021 